\title{
PENERAPAN BIAH LUGHAWIYAH DALAM PEMBIASAAN \\ MAHARAH KALAM DI PONDOK PESANTREN IBNUL QAYYIM PUTRA YOGYAKARTA
}

\author{
Widi Astuti, Cahya Edi Setyawan, Irvan Maulana Aji \\ STAI Masjid Syuhada \\ Widi280990@gmail.com,cahya.edi24@gmail.com,
}

\begin{abstract}
ملخص
كان الغرض من هذه الدراسة هو تحديد كيفية تطبيق البيئة اللغوية في محاولة لتعويد إتقان التحدث باللغة العربية (المهرة الكلام) في المدرسة إبن القيم الإسلامية للرجال . في يوكياكرتا . نوع هذا البحث هو البحث النوعي ·تم جمع البيانات من خلال الملاحظة الدقيقة، بما في ذلك الأوصاف في السياق المفصل، وأطروحة من الماحظة من المقابلة المتعمقة، وكذلك نتائج تحليل الوثائق . هناك عدة أنواع من الأنثطة في تطبيق بيئة لغوية، وهي : إضافة المفردات، وممارسة

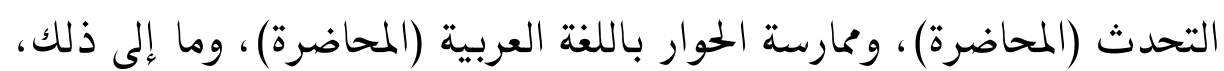
والتي تُستخدم لدعم مهارة اللغة العربية لدى الطلاب في المدرسة الثانوية وكذلك في المدرسة الثانوية بعهد إبن القيم للرجال. الكلمات المفتاحية : تنفيذ بيئة لغوية ، مهارة الكلام
\end{abstract}

\section{Pendahuluan}

Salah satu indikasi atau yang menunjukkan seseorang itu dikatakan menguasai bahasa Arab adalah jika terbukti bahwa secara verbal dia dapat berbicara dengan bahasa tersebut, karena hakekat bahasa adalah berbicara atau berucap (berujar). Meskipun 
Widi Astuti, Cahya Edi Setyawan, Irvan Maulana Aji : Penerapan Biah Lughawiyah Dalam Pembiasaan Maharah Kalam Di Pondok Pesantren Ibnul Qayyim Putra Yogyakarta

seseorang telah menguasai tata bahasa ( $\left.q a w a^{\prime} i d\right)$ belum tentu ia mampu berucap dengan baik pula63. Apabila sekolahan diumpamakan sebagai tempat mengolah sesuatu dan siswa diumpamakan sebagai bahan mentah maka lulusan dari sekolah tersebut dapat disamakan dengan hasil olahan yang sudah siap digunakan. Diibaratkan sebuah mesin, ada proses transformasi yang menurut bahasa inggris berasal dari dua kata yaitu trans : terjemahan atau perubahan dan form : bentuk. Jadi transformasi dalam pembelajaran dapat diartikan sebagai proses pergantian atau perubahan bentuk, seorang siswa dari yang sebelumnya belum mengetahui sesuatu menjadi tahu. ${ }^{64}$

Aktivitas santri di lingkungan pondok pesantren Ibnul Qoyyim Putra dengan segala bentuk kegiatan, menuntut santri untuk bisa membagi waktu dengan baik. Salah satu kegiatan yang tidak bisa lepas yaitu berinteraksi atau berbicara sesama santri dengan memakai bahasa Arab dan Inggris sebagai bahasa seharihari atau dalam bahasa Arabnya yaitu Bi'ah Lughowiyyah. Sistem ini sudah menjadi kewajiban bagi seluruh elemen santri dari kelas 1 KMI sampai kelas 6 KMI. Dalam prakteknya yang secara sistematis telah tersusun dalam buku pedoman santri, pengawasan dilakukan oleh pengurus dengan menugaskan kelas $5 \mathrm{KMI}$ serta ustadz atau

63Muhammad Husain al-Aziziy, Madkhal ila ilmil lughah, (Kairo: Dar Ulum, 1991), hlm: 12

64 Suharsimi Arikunto, Dasar-dasar Evaluasi Pembelajaran, (PT. Bumi Aksara,2012), hlm 4-5

\section{IHTIMAM}


Widi Astuti, Cahya Edi Setyawan, Irvan Maulana Aji : Penerapan Biah Lughawiyah

Dalam Pembiasaan Maharah Kalam Di Pondok Pesantren Ibnul Qayyim Putra Yogyakarta

musyrif pembimbing guna mengontrol praktek penggunaan bahasa Arab dan Inggris.

Seiring berjalanya waktu dengan semakin bertambahnya jumlah santri, kondisi dan situasi lingkungan pesantren semakin kompleks terutama dalam pemakaian bahasa Arab. Berdasarkan observasi yang telah dilakukan penulis, pemerataan penggunaan bahasa Arab yang semakin menurun menjadi pokok permasalahan sendiri di pondok pesantren ${ }^{65}$. Ada beberapa penelitian terdahulu yang menjadi acuan peneliti dalam meneliti judul ini, yaitu 1) penelitian yang ditulis oleh Dinni Masyitoh Lindriani Wati dengan judul, "Peningkatan Keterampilan Berbahasa Arab Dengan Kegiatan Debat Berbahasa Arab Untuk Mahasiswa Semester Dua Pendidikan Bahasa Arab Universitas Muhammadiyah Yogyakarta Tahun ajaran 2016/2017". Jenis penelitianya adalah kuntitatif. Aspek yang diteliti adalah proses peningkatan berbahasa arab mahasiswa semester dua Pendidikan Bahasa Arab Universitas Muhammadiyah dengan metode debat berbahasa arab66, 2) penelitian selanjutnya adalah oleh Avick Ashari dengan NIM 20090720032 jurusan Pendidikan Agama Islam, Fakultas Agama Islam Universitas Muhammadiyah Yogyakarta tahun 2012 dengan judul, "Peranan Pembimbing Asrama Dalam Meningkatkan

65 Wawancara dengan musyrif bahasa, di Kantor Pondok Pesantren Ibnul Qoyyim Putra, Tanggal 4 November 2019, Pukul 11.00 WIB.

66 Dinni Masyitoh Lindriani Wati, Skripsi: "Peningkatan Keterampilan Berbahasa Arab Dengan Kegiatan Debat Berbahasa Arab Untuk Mahasiswa Semester Dua Pendidikan Bahasa Arab 
Widi Astuti, Cahya Edi Setyawan, Irvan Maulana Aji : Penerapan Biah Lughawiyah Dalam Pembiasaan Maharah Kalam Di Pondok Pesantren Ibnul Qayyim Putra Yogyakarta

Keterampilan Berbahasa Arab Dan Inggris Siswa Madrasah Mu'alimin Muhammadiyah Yogyakarta". Jenis penelitianya adalah kualitatif, sedangkan teknik pengumpulan data yaitu wawancara, observasi, angket, dokumentasi. Aspek yang diteliti adalah peranan pembimbing asrama dalam meninkatkan keterampilan berbahasa siswa Madrasah Mu'alimin Muhammadiyah Yogyakarta (Studi Kasus Asrama Multilingual) ${ }^{67}$.

Penelitian selanjutnya adalah 3) oleh Yuniar Eka Rustika dari Fakultas Ilmu Tarbiyah dan Keguruan Universitas Islam Negeri Sunan Kalijaga, tahun 2014 yang berjudul " Upaya Penciptaan Bi'ah Lughowiyyah Melalui Optimalisasi Pembelajaran Al-Kalam di Jurusan Pendidikan Bahasa Arab Fakultas Ilmu Tarbiyyah dan Keguruan UIN Sunan Kalijaga Yogyakarta" Studi kasus mahasiswa jurusan PBA angkatan 2011/2012. Penelitian tersebut merupakan penelitian kualitatif dengan pendekatan deskriptuf, pengumpulan data dilakukan observasi, wawancara dan dokumentasi. ${ }^{68}$

67 Avick Ashari, Skripsi : "Peranan Pembimbing Asrama Dalam Meningkatkan Keterampilan Berbahasa Arab Dan Inggris Siswa Madrasah Mu'alimin Muhammadiyah Yogyakarta ",(Yogyakarta: Universitas Muhammadiyah Yogyakarta,2012)

68 Yuniar Eka Rustika, Skripsi : “Upaya Penciptaan Bi'ah Lughowiyyah Melalui Optimalisasi Pembelajaran Al-Kalam di Jurusan Pendidikan Bahasa Arab Fakultas Ilmu Tarbiyyah dan Keguruan UIN Sunan Kalijaga Yogyakarta". (Yogyakarta, Universitas Islam Negri Sunan Kalijaga, 2014)

\section{IHTIMAM}


Widi Astuti, Cahya Edi Setyawan, Irvan Maulana Aji : Penerapan Biah Lughawiyah

Dalam Pembiasaan Maharah Kalam Di Pondok Pesantren Ibnul Qayyim Putra Yogyakarta

\section{Pemahaman Bi'ah Lughowiyyah}

Pada hakikatnya lingkungan merupakan sumber belajar yang bersifat alami. Seseorang dapat mengetahui dan mempelajari tentang berbagai hal melalui lingkungan. Seperti tentang bahasa, alam, keterampilan, kesenian, kesehatan dan sebagainya ${ }^{69}$. Contohnya seperti lingkungan sosial yang merupakan salah satu tempat interaksi seseorang dengan orang lain disekitarnya. Hasil interaksi dapat menambah pengetahuan seseorang tentang berbagai hal, seperti berkomunikasi, maka orang tersebut dapat belajar tentang bahasa dan tutur kata yang baik. Kata bi'ah berasal dari bahasa Arab البئة yang berarti lingkungan dan حالة kondisi. Sedangkan lughowiyyah لغوبة berarti bahasa. Adapun bi'ah lughowiyyah yang dimaksud dalam penelitian ini adalah lingkungan yang mana setiap kegiatan yang berlangsung didalamnya menggunakan bahasa arab baik secara aktif maupun pasif. 70

Lingkungan bahasa sangat berperan penting dalam proses belajar bahasa arab karena akan membentuk kebiasaan, rangsangan dan stimulus sehingga dari kebiasaan tersebut terbentuk kelancaran berbahasa arab. Dengan adanya bi'ah lughawiyyah diharapkan timbul peran antar pelajar dalam berkomunikasi bahasa Arab di setiap aktivitas sehari-hari sehingga mampu

69 Abdul Wahid Wafi, Al Lughah wa Al Mujtama', (Kairo: Dar alNahdhat Mishr, 1971), hlm 11

70 Neli Putri, Al-Ta'lim : “Bi'ah 'Arabiyyah", (IAIN Imam Bonjol Padang, 2013, Volume 1, Nomor 5), hlm 407-413 
Widi Astuti, Cahya Edi Setyawan, Irvan Maulana Aji : Penerapan Biah Lughawiyah Dalam Pembiasaan Maharah Kalam Di Pondok Pesantren Ibnul Qayyim Putra Yogyakarta

meningkatkan motivasi para pelajar untuk tergerak hati dan lisannya untuk melakukan interaksi komunikasi berbahasa Arab.

\section{Tujuan Penciptaan Bi'ah Lughowiyyah}

Secara umum penciptaan atau pembentukan lingkungan bahasa arab (bi'ah lughowiyyah) sebagai berikut :

1. Menumbuhkan tradisi positif dalam belajar bahasa arab aktif, serta memanfaatkan bahasa secara komunikatif melalui percakapan (muhadatsah), diskusi (munaqasyah), ceramah/ pidato (muhadharah), dan berekspresi melalui tulisan (insya').

2. Memberikan penguatan pemerolehan bahasa yang sudah dipelajari di dalam kelas, sehingga siswa lebih memiliki kesempatan mempraktekan bahasa arab.

3. Menumbuhkan kreativitas dan aktivitas belajar bahasa arab, sehingga dapat memadukan antara teori dan praktik dalam lingkungan yang menyenangkan.

\section{Prinsip Bi'ah Lughowiyyah}

1. Prinsip keterpaduan visi, misi dan orientasi pembelajaran bahasa Arab.

Sebelum berjalanya bi'ah lughowiyyah sebagai sebuah program yang yang sistematis perlu menyusun tujuan yang jelas. Berupa visi dan misi serta orientasi kedepanya sebagai sebuah tujuan akhir dari proses berlangsungnya lingkungan berbahasa. Hal ini untuk memudahkan bagi komponen pengajar 
Widi Astuti, Cahya Edi Setyawan, Irvan Maulana Aji : Penerapan Biah Lughawiyah

Dalam Pembiasaan Maharah Kalam Di Pondok Pesantren Ibnul Qayyim Putra Yogyakarta

maupun pelajar dalam proses belajar bahasa arab. Dengan program yang jelas serta kesatuan tujuannya maka hasil yang akan diperoleh bisa dimaksimalkan.

2. Prinsip skala prioritas dan gradasi program.

Implementasi pembentukan lingkungan bahasa harus dilakukan secara bertahap. Dalam prosesnya perlu adanya pembagian skala prioritas sehingga memudahkan dalam prakteknya. Sebagai contoh memulai kebiasaan yang sederhana seperti ucapan salam, tegur sapa dan lain sebagainya yang mana awal tersebut sebagai prioritas dasar. Kemudian dilanjutkan dengan tingkatan atasnya seperti percakapan harian.

3. Prinsip kebersamaan dan partisipasi aktif semua pihak.

Proses yang terpadu dan saling bahu membahu dari semua pihak yang terlibat dalam pembentukan lingkungan bahasa, sehingga kebersamaan dan partisipasi aktif akan menunjang keberhasilan tersebut.

4. Prinsip konsistensi dan berkelanjutan.

Sikap konsisten dalam lingkungan berbahasa itu sangat sulit sekali karena diperlukan sebuah sistem yang variatif dan kreatif yang memungkinkan satu sama lain saling mengontrol dan membudayakan penggunaan bahasa secara aktif.

5. Prinsip pendayagunaan teknologi dan multi media.

Media penunjang sebagai sarana pembelajaran bahasa arab perlu dioptimalkan, karena untuk memudahkan proses 
Widi Astuti, Cahya Edi Setyawan, Irvan Maulana Aji : Penerapan Biah Lughawiyah Dalam Pembiasaan Maharah Kalam Di Pondok Pesantren Ibnul Qayyim Putra Yogyakarta

belajar pelajar. Seperti contoh melalui tayangan vidio berbahasa arab di komputer, hal tersebut akan menambah referensi ${ }^{71}$.

6. Strategi penciptaan Biah Lughowiyyah

a. Menciptakan lingkungan bahasa arab formal

Lingkungan formal yang dimaksud disini adalah lingkungan kelas. Agar lingkungan formal dapat maksimal membantu proses perolehan wacana bahasa, maka perlu adanya kerjasama yang baik antara guru dan siswa. Guru yang mengajar dikelas harus merancang sumber daya yang ada didalam kelas untuk dijadikan media dalam memperkaya wacana siswa. Seperti contoh guru menulis tanggal, hari, dan mata pelajaran di papan tulis menggunakan bahasa arab. Hal ini dapat membantu siswa dengan mengetahui dan membiasakan menggunakan bahasa arab. ${ }^{72}$

Lebih lanjut lagi, untuk menciptakan lingkungan bahasa arab non formal perlu pendekatan komunikatif, quantum, dan kontekstual, yaitu dengan cara sebagai berikut: 1) Menggunakan strategi interaksionis, yaitu mememusatkan kegiatan siswa pada kegiatan yang bersifat komunikatif dan meminimalisir penjelasan tentang kaidah, agar suaya siswa lebih banyak berbicara.

71 M. Rizal Risqi, Alfazuna : "Peran Bi'ah Lughowiyyah Dalam Meningkatkan Pemerolehan Bahasa Arab", (Daarul 'Ulum Lamongan, 2016, Volume 1, Nomor 1), hlm 135-136

72 Neli Putri, loc cit 
Widi Astuti, Cahya Edi Setyawan, Irvan Maulana Aji : Penerapan Biah Lughawiyah

Dalam Pembiasaan Maharah Kalam Di Pondok Pesantren Ibnul Qayyim Putra

2) Memvariasikan materi dengan memperbanyak bahan otentik atau dasar kemudian memperhatikan prinsip kebermaknaan, keterpakaian, dan menarik.

3) Memperluas wawasan kebahasaan melalui tugas baca buku, majalah, koran berbahasa arab, mendengar siaran radio arab, vcd, dan lainya.

4) Guru adalah motivator dan fasilitator saja, yang akan berbicara banyak dan doiminan adalah siswa.

5) Menggunakan metode dan teknik yang variatif yang tidak bertentangan dengan pendekatan yang ditetapkan.

b. Menciptakan lingkungan bahasa arab informal

Lingkungan informal yaitu lingkungan berbahasa arab diluar kelas. Bi'ah lughowiyyah yang sebenanrnya adalah yang berada di daerah atau negara-negara Arab. Untuk bisa memenyamainya maka dibuatlah sebuah sistem pembiasaan dalam kegiatan sehari hari.

Lingkungan informal lebih luas cakupanya dibandingkan lingkungan formal kelas. Berbagai pihak ikut dilibatkan dalam proses pembelajaran bahasa arab melalui lingkungan informal ini, sperti para guru, kakak atau adik kelas.

Menurut Efendy ada tiga syarat yang harus dipenuhi untuk mewujudkan hal itu, yakni:

1) Adanya sikap positif dari pihak-pihak terkait, seperti: kepala sekolah, guru bahasa Arab, siswa dan seluruh SDM 
Widi Astuti, Cahya Edi Setyawan, Irvan Maulana Aji : Penerapan Biah Lughawiyah

Dalam Pembiasaan Maharah Kalam Di Pondok Pesantren Ibnul Qayyim Putra

Yogyakarta

sekolah, baik tenaga kependidikan maupun non kependidikan juga ikut mendukungnya,

2) Adanya central figur yang mampu berkomunikasi menggunakan bahasa Arab, dan

3) Adanya alokasi dana yang memadai untuk menyediakan sarana yang diperlukan ${ }^{73}$

Untuk menciptakan lingkungan informal membutuhkan waktu yang lebih lama, ketelatenan, kesabaran, dan kosistensi. Adapun strategi yang bisa dilakukan sebagai berikut :

1) Menyediakan lingkungan yang kondusif, terpadu, serta terprogram. Seperti wajib menggunakan bahasa arab sesuai waktu, tempat, dan kondisi yang telah disepakati. Kemudian memberikan sanksi yang edukatif bagi siswa yang tidak menjalankan peraturan yang telah dibuat. Selanjutnya menciptakan lingkungan psikologis secara baik, yaitu dengan memberikan stimulus atau pengertian kepada siswa tentang peranan bahasa arab atau pentingnya bahasa arab, sehingga siswa akan termotivasi dan terdorong semangatnya untuk terus mempelajari bahasa arab.

73 Ahmad Fuad Efendy, Metodologi Pengajaran Bahasa Arab, (Malang: Misykat, 2005), hlm 141 
Widi Astuti, Cahya Edi Setyawan, Irvan Maulana Aji : Penerapan Biah Lughawiyah

Dalam Pembiasaan Maharah Kalam Di Pondok Pesantren Ibnul Qayyim Putra Yogyakarta

2) Menyiapkan SDM yang mempunyai kompetensi komunikatif lisan maupun tulisan yang berperan sebagain model bagi siswa (lawan komunikasinya).

3) Membentuk kelompok pecinta bahasa arab dengan mengadakan kegiatan-kegiatan yang bernuansa arab, seperti latihan pidato berbahasa arab, diskusi, pemutaran film, lagu dan lainya.

4) Mengadakan pekan arabiy dengan mengadakan berbagai perlombaan seperti lomba pidato, debat, mengarang puisi, drama dan lain sebagainya.

5) Menyediakan Self Acces Centre (SAC), yaitu tempat khusus untuk mengakses bermacam-macam pengetahuan terkait bahasa arab secara mandiri tanpa adanya bimbingan dari guru. Rang ini tempat ini dilengkapi dengan berbagai media elektronik seperti audio visual, komputer, serta internet.

c. Media penunjang pengembangan lingkungan bahasa

Ada beberapa media yang dapat menunjang pengembangan lingkungan bahasa arab, meliputi :

1) Ruang halaqoh

Media ini disediakan untuk kajian ilmiah, diskusi, yang dilengkapi dengan buku-buku bahasa arab. Pemberian materi-materi berkaitan tentang bahasa arab juga dapat disampaikan di ruang halaqoh untuk menunjang pemerolehan bahasa arab pelajar. 
Widi Astuti, Cahya Edi Setyawan, Irvan Maulana Aji : Penerapan Biah Lughawiyah Dalam Pembiasaan Maharah Kalam Di Pondok Pesantren Ibnul Qayyim Putra Yogyakarta

2) Kelas terbuka

Media ini bertujuan untuk menciptakan suasana yang menyenangkan bagi siswa, mengurangi kejenuhan, memberikan variasi dan inovasi pembelajaran di ruang terbuka. Sehingga diharapkan siswa mampu menyerap materi dengan maksimal.

3) Laboratorium bahasa

Media ini merupakan sarana pengembangan bahasa. Didalamnya terdapat berbagai macam materi bahasa arab seperti rekaman muhadatsah atau percakapan, pidato, jurnal berbahasa arab dan lain sebagainya.

4) Audio visual bahasa arab

Media penunjang ini memuat beberapa rekaman muahadatsah, pidato, serta terjemah kitab bahasa arab. Selanjutnya memuat rekaman seminar dan vidio terkait pembelajaran bahasa arab sehingga siswa atau pelajar mampu menangkap materi serta pengaplikasianya dalam bentuk pengayaan yang disediakan oleh pengajar.

\section{Pemahaman Maharah Kalam}

Secara terminologi kalam berasal dari bahasa Arab (al-kalam) yang bermakna perkataan atau ucapan. Dilihat dari segi epistemologi, kalam adalah pengucapan bunyi-bunyi berbahasa Arab dengan baik dan benar sesuai dengan bunyi-bunyi yang 
Widi Astuti, Cahya Edi Setyawan, Irvan Maulana Aji : Penerapan Biah Lughawiyah

Dalam Pembiasaan Maharah Kalam Di Pondok Pesantren Ibnul Qayyim Putra

berasal dari makhraj yang dikenal oleh para linguistik ${ }^{74}$. Sedangkan mahārah kalam adalah kemampuan seseorang dalam pengucapan artikulasi atau kata-kata untuk mengungkapkan gagasan, ide, pikiran dan pendapat kepada lawan berbicara atau orang lain ${ }^{75}$.

Kemampuan berbicara adalah bagian dari keterampilan yang dipelajari oleh para pembelajar bahasa arab, sehingga kemampuan dalam berbicara (maharah kalam) aktif maupun pasif sebagai bagian yang mendasar dari sebuah proses belajar bahasa arab.

Pembelajaran bahasa arab khususnya maharah kalam yang akan atau sedang berlangsung bagi pengajar harus memiliki konsep serta tujuan yang tersusun secara sistematis dan jelas, karena melihat begitu mendasar pembelajaran maharah kalam ini.

\section{Tujuan Maharah Kalam}

Tujuan dari pembelajaran maharah kalam (keterampilam berbicara) mencakup beberapa hal antara lain :

1. Kemampuan berbicara

Dari proses pembelajaran dan pembentukan keterampilan berbicara (maharah kalam), diharapkan peserta didik mampu mengucapkan artikulasi atau bunyi-bunyi kata bahasa arab dengan baik dan benar. Prakteknya bisa dengan orang lain dalam kelompok kecil sampai dengan dihadapan umum yang jumlahnya lebih banyak. Peserta didik dilatih untuk

${ }^{74}$ Kuswoyo, loc it

75 Acep Hermawan, Metodologi Pembelajaran Bahasa Arab, (Bandung: Remaja Rosdakarya, 2011), hlm 135 
Widi Astuti, Cahya Edi Setyawan, Irvan Maulana Aji : Penerapan Biah Lughawiyah

Dalam Pembiasaan Maharah Kalam Di Pondok Pesantren Ibnul Qayyim Putra

Yogyakarta

menumbuhkan percaya diri dalam berbicara dengan bahasa arab dihadapan orang lain.

2. Kejelasan

Dalam hal ini peserta didik berbicara dengan tepat dan jelas, baik artikulasi maupun diksi kalimat-kalimatnya. Gagasan yang diucapkan harus tersusun dengan baik, agar kejelasan dalam berbicara tersebut dapat dicapai, maka dibutuhkan berbagai macam latihan terus menerus dan variatif. Bisa melalui diskusi, pidato, dan debat. Karena dengan latihan seperti ini akan dapat mengatur cara berfikir seseorang dengan sistematis dan logis.

3. Bertanggung jawab

Berbicara yang baik dan benar menuntut seseorang untuk bertangguung jawab atasa apa yang diucapkan dengan berbicara yang tepat, benar, serta difikirkan dengan sungguhsungguh mengenai apa yang menjadi topik pembicaraan dengan lawan berbicara.

4. Membentuk pendengaran kritis

Latihan berbicara yang baik sekaligus mengembangkan keterampilan menyimak secara tepat dan kritis juga menjadi tujuan utama program pembelajaran ini. Di sini peserta didik perlu belajar untuk dapat mengevaluasi kata-kata yang telah diucapkan, niat ketika mengucapkan, dan tujuan dari pembicaraan tersebut. 
Widi Astuti, Cahya Edi Setyawan, Irvan Maulana Aji : Penerapan Biah Lughawiyah

Dalam Pembiasaan Maharah Kalam Di Pondok Pesantren Ibnul Qayyim Putra Yogyakarta

5. Membentuk kebiasaan

Kebiasaan berbicara menggunakan bahasa arab tidak akan berjalan lancar tanpa adanya niat serta usaha yang sungguh-sungguh dari proses belajar bahasa arab seperti pembiasaan maharah kalam ${ }^{76}$.

Proses pembiasaan berawal dari diri sendiri kemudian dengan kelompok berbicara kecil, sehingga dapat menunjang keterampilan berbicara bahasa arab.

\section{Langkah-langkah pembelajaran Maharah Kalam}

Adapun langkah-langkah yang bisa dilakukan guru dalam proses pembelajaran kalam sebagai berikut :

1. Bagi pembelajar mubtadi' (pemula)

a. Guru mulai melatih bicara dengan memberi pertanyaanpertanyaan yang harus dijawab oleh siswa.

b. Pada saat bersamaan siswa diminta untuk belajar mengucapkan kata, menyusun kalimat dan mengungkapkan pikiran.

c. Guru mengurutkan pertanyaan-pertanyaan yang dijawab oleh siswa sehingga berakhir membentuk sebuah tema yang sempurna.

d. Guru bisa menyuruh siswa menjawab latihan-latihan syawafiyyah, menghafal percakapan, atau menjawab

76 Syaiful Mustofa, Strategi Pembelajaran Bahasa Arab Inovatif, (Malang: UIN MALIKI PRESS,2011), hal 138-140 
Widi Astuti, Cahya Edi Setyawan, Irvan Maulana Aji : Penerapan Biah Lughawiyah Dalam Pembiasaan Maharah Kalam Di Pondok Pesantren Ibnul Qayyim Putra

Yogyakarta

pertanyaan yang berhubungan dengan isi teks yang telah siswa baca.

2. Bagi pembelajar mutawasitah (lanjutan)

a. Belajar berbicara dengan bermain peran.

b. Berdiskusi tentang tema tertentu.

c. Bercerit tentang peristiwa-peristiwa yang terjadi pada siswa.

d. Bercerita tentang informasi yang telah didengar dari televisi, radio, atau lainya.

3. Bagi pembelajar mutaqaddim (tingkat atas)

a. Guru memilihkan tema untuk berlatih kalam.

b. Tema yang dipilih hendaknya menarik dan berhubungan dengan kehidupan siswa.

c. Tema harus jelas dan terbatas.

d. Mempersilahkan siswa memilih dua tema atau lebih sampai akhirnya siswa bebas memilih tema yang dibicarakan tentang apa yang mereka ketahui ${ }^{77}$.

\section{Penerapan Bi'ah Lughowiyyah dalam Pembiasaan Maharah Kalam}

Sebelum berjalanya bi'ah lughowiyyah sebagai sebuah program yang sistematis perlu menyusun tujuan yang jelas. Berupa visi dan misi serta orientasi kedepanya sebagai sebuah tujuan akhir dari proses berlangsungnya lingkungan berbahasa. Dengan

77 Bisri Mustofa dan Abdul Hamid, Metode Dan Strategi Pembelajaran Bahasa Arab, (Malang: UIN MALIKI PRESS, 2012), hlm 88-89 
Widi Astuti, Cahya Edi Setyawan, Irvan Maulana Aji : Penerapan Biah Lughawiyah

Dalam Pembiasaan Maharah Kalam Di Pondok Pesantren Ibnul Qayyim Putra

program yang jelas serta kesatuan tujuannya maka hasil yang akan diperoleh bisa dimaksimalkan. Dari hasil penelitian yang penulis lakukan, dapat di presentasikan sebagai berikut :

1. Bentuk kegiatan pembiasaan maharah kalam dengan kegiatan bi'ah lughowiyyah yaitu :

a. Wajib memakai bahasa arab 24 jam.

Dalam berinteraksi dengan orang lain, para santri diwajibkan menggunakan bahasa arab di seluruh area pondok pesantren untuk melatih dan membiasakan penggunaan bahasa arab. Dalam pengkondisian dan pengontrolan penggunaan bahasa para pengurus harian atau mudabbir terkhusus bagian bahasa akan memilih mata-mata (jasus) bahasa untuk mencatat bagi siapa saja yang tidak memakai bahasa arab dalam berkomunikasi dengan lawan bicara. Selanjutnya penindakan bagi yang melanggar peraturan berbahasa akan di berikan hukuman yang sifatnya edukatif dan berefek jera, seperti mencari kosa kata baru dengan jumlah yang ditentukan atau bersih-bersih lingkungan ${ }^{78}$.

Analisa dalam program kewajiban berbahasa 24 jam ini sangat baik. Lingkungan bahasa sangat berperan penting dalam proses belajar bahasa arab karena akan membentuk

78 Observasi kegiatan penggunaan bahasa arab, di komplek lingkungan Pondok Pesantren Ibnul Qoyyim Putra, Tanggal 1 Oktober 2019- 1 September 2020. 
Widi Astuti, Cahya Edi Setyawan, Irvan Maulana Aji : Penerapan Biah Lughawiyah Dalam Pembiasaan Maharah Kalam Di Pondok Pesantren Ibnul Qayyim Putra Yogyakarta

kebiasaan, rangsangan serta stimulus sehingga dari kebiasaan tersebut terbentuk kelancaran berbahasa. Dengan adanya bi'ah lughowiyyah diharapkan timbul peran antar santri dalam berkomunikasi berbahasa arab di setiap aktivitas sehari-hari sehingga mampu meningkatkan motivasi para santri untuk tergerak hati dan lisanya untuk melakukan interaksi komunikasi berbahasa arab khususnya.

b. Muhadatsah (berdialog).

Kegiatan ini dilaksanakan pada hari Jum'at pagi dan Minggu pagi. Dimulai pada pukul 05.30 sampai 06.00. Bentuk kegiatanya yaitu para pengurus harian santri (mudabbir) menyampaikan materi muhadatsah sesuai dengan buku pedoman. Seperti contoh bertemakan tentang percakapan di ruang makan. Mudabbir membacakan kemudian diikuti oleh para santri yang lain. Selanjutnya, setelah pembacaan bersama, santri memahami dan mempraktekan langsung dengan lawan bicaranya. Untuk tujuan muhadatsah adalah melatih lidah santri agar terbiasa dan fasih berdialog dalam bahasa arab, terampil berbicara dalam bahasa arab mengenai kejadian yang terjadi dalam kehiduan sehari-hari, mampu menerjemahkan percakapan orang lain, dan menumbuhkan rasa cinta dan menyenangi bahasa arab dan Al Qur'an.

c. Muhadoroh (pidato).

Kegiatan ini dilaksanakan pada hari senin malam dan kamis malam. Dimulai pukul 20.00 sampai 21.30 dengan 
Widi Astuti, Cahya Edi Setyawan, Irvan Maulana Aji : Penerapan Biah Lughawiyah Dalam Pembiasaan Maharah Kalam Di Pondok Pesantren Ibnul Qayyim Putra

dibimbing langsung oleh musyrif bahasa yaitu para ustadz serta didampingi oleh pengurus harian santri. Bentuk kegiatanya yaitu di awal pertemuan semua santri diberikan materi-materi tentang muhadharah. Seperti latihan pembuatan teks pidato yang baik dan benar, pengucapan intonasi serta gerak tubuh saat penyampaian. Selanjutnya para santri dijadwalkan untuk maju berpidato di depan khalayak ramai dengan tema yang sudah ditentukan menggunakan bahasa arab. Contohnya bertemakan tentang berbakti kepada orang tua. Mudabbir bahasa akan memberikan informasi kepada para santri untuk membuat teks pidato, kemudian setelah selesai pembuatan akan di koreksi terlebih dahulu sebelum maju untuk berpidato.

d. Pemberian Mufrodat (kosa-kata).

Kegiatan pemberian mufrodat dilaksanakan pada hari selasa dan rabu pagi pada pukul 05.30 sampai 06.00 . Santri dipisahkan sesuai jenjang kelas kemudian pengurus menyampaikan mufrodat, baik berupa kosa-kata baru atau mengulangi kosa-kata yang sudah dihafal. Kemudian setelah menghafal, santri dipersilahkan untuk membuat kalimat baru dengan menggunakan kosa-kata yang telah disampaikan atau dihafal. Setelah itu santri dipersilahkan untuk mengumpulkan bentuk kalimat baru kepada mudabbir dan langsung untuk dikoreksi. Untuk tempat kegiatan bervariasi, bisa dikelas ataupun di halaman. 
Widi Astuti, Cahya Edi Setyawan, Irvan Maulana Aji : Penerapan Biah Lughawiyah Dalam Pembiasaan Maharah Kalam Di Pondok Pesantren Ibnul Qayyim Putra Yogyakarta

e. Language club (club bahasa) dan Pelatihan Debat.

Kegiatan ini dikhususkan bagi santri yang mempunyai minat lebih terhadap bahasa arab. Mereka akan mendapatkan materi-materi tambahan yang sudah di persiapkan oleh pengurus harian santri ataupun musyrif. Seperti materi nahwu, insya', mempelajari dari audio visual yang memuat pembelajaran bahasa arab dan lain sebagainya. Kemudian latihan debat berbahasa arab dilaksanakan minimal sebulan sekali dengan peserta beberapa santri yang telah dipilih oleh pengurus dan diberi materi mengenai kegiatan debat berbahasa arab. Kemudian mepraktekan debat disaksikan oleh seluruh santri ${ }^{79}$.

Manfaat dari kegiatan bi'ah lughowiyyah adalah sebagai berikut :

a. Menambah ilmu pengetahuan dan wawasan khususnya bahasa arab

b. Melatih tanggung jawab para santri untuk menggunakan bahasa arab secara baik dan benar. Mempertimbangkan apa yang akan diucapkan kepada lawan bicara. Sehingga tata bahasa yang diucapkan sesuai dengan kaidah-kaidah bahasa arab.

79 Wawancara dengan Mudabbir bahasa, di Masjid Pondok Pesantren Ibnul Qoyyim Putra, Tanggal 29 Januari 2020, Pukul 14.30 WIB 
Widi Astuti, Cahya Edi Setyawan, Irvan Maulana Aji : Penerapan Biah Lughawiyah Dalam Pembiasaan Maharah Kalam Di Pondok Pesantren Ibnul Qayyim Putra Yogyakarta

c. Melatih kesadaran akan pentingnya bahasa Arab khususnya sebagai umat islam yang merupakan bahasa kitab suci $\mathrm{Al}$ Qur'an.

d. Kegiatan bi'ah lughowiyyah meningkatkan motivasi santri untuk bersemangat dalam berkomunikasi menggunakan bahasa arab.

2. Faktor Pendukung dan Penghambat Bi'ah Lughowiyyah

a. Faktor pendukung kegiatan bi'ah lughowiyyah

Faktor yang mendukung keberlangsungan kegiatan bi'ah lughowiyyah di lingkungan Pondok Pesantren Ibnul Qoyyim Putra sebagai berikut:

1) Musyriflughoh

Peran musyrif atau pembimbing disini begitu penting karena untuk membimbing dalam pembuatan program kegiatan bahasa, mengontrol, dan mengevaluasi setiap kegiatan. Musyrif juga akan selalu memberikan motivasi serta semangat kepada pengurus harian santri ataupun kepada seluruh santri untuk selalu bersemangat dalam menuntut ilmu.

2) Media pembelajaran

Faktor pendukung bi'ah lughowiyyah selanjutnya yaitu tersedianya media-media yang menunjang setiap kegiatan, seperti kitab-kitab berbahasa arab, buku muhadatsah, buku mufrodat, dan buku-buku pengetauan lainya yang mengenai bahasa arab. 
Widi Astuti, Cahya Edi Setyawan, Irvan Maulana Aji : Penerapan Biah Lughawiyah Dalam Pembiasaan Maharah Kalam Di Pondok Pesantren Ibnul Qayyim Putra Yogyakarta

3) Sarana prasarana

Dalam menjalankan sebuah program pembelajaran di luar kelas perlu tersedianya sarana dan prasarana yang memadai. Dalam hal ini sarana yang tersedia yaitu ruang halaman pesantren yang luas akan memudahkan setiap kegiatan yang berlangsung. Kemudian suasana pesantren yang berdampingan dengan sawah memberi kesan yang tentram dan asri sejuk, sehingga para santri akan merasa nyaman tinggal di pesantren dan memaksimalkan kegiatan yang ada.

3. Faktor penghambat kegiatan bi'ah lughowiyyah

Keadaan semangat atau mood perasaan yang sedang dialami seseorang akan mempengaruhi pembawaan jiwanya. Hal ini yang menjadikan faktor penghambat sebuah kegiatan yang dilaksanakan. Ketika ada beberapa santri yang sedang turun semangat dan akan sangat berpengaruh pada konsentrasi didalam kegiatan bi'ah lughowiyyah. Faktor seperti ini menjadi tanggung jawab bagi semua pihak mulai dari teman seperjuangan untuk bisa memotivasinya, pengurus harian santri, serta para musyrif sehingga dengan dorongan motivasi dan semangat akan kembali memunculkan semangat untuk bisa lebih giat dalam menuntut ilmu dan mengikuti semua kegiatan bi'ah lughowiyyah. 
Widi Astuti, Cahya Edi Setyawan, Irvan Maulana Aji : Penerapan Biah Lughawiyah

Dalam Pembiasaan Maharah Kalam Di Pondok Pesantren Ibnul Qayyim Putra Yogyakarta

\section{Kesimpulan}

Berdasarkan hasil penelitian ini, penulis menyimpulkan berbagai hal mengenai penerapan bi'ah lughowiyyah dalam pembiasaan maharah kalam serta faktor pendukung dan pemnghambatnya, sebagai berikut :

1. Penerapan bi'ah lughowiyyah dalam pembiasaan maharah kalam yaitu dengan mewajibkan menggunakan bahasa arab 24 jam, kemudian kegiatan muhadatsah (berdialog), muhadoroh (pidato), mufrodat (kosa-kata), language club, dan latihan debat. Kemudian bimbingan motivasi dari para musyrif dan pengurus harian santri sehingga tercipta semangat yang tinggi akan pentingnya belajar bahasa arab.

2. Dalam setiap kegiatan memungkinkan adanya faktor pendukung dan penghambatnya. Adapun faktor pendukungnya adalah peran musyrif yang selalu membimbing dan mengarahkan setiap kegiatan serta memberikan dorongan semangat motivasi. Kemudian faktor media pembelajaran yang tersedia seperti kitab-kitab klasik, buku muhadatsah, serta bukubuku yang menunjang kegiatan pembelajaran. Faktor selanjutnya adalah sarana prasarana seperti perpustakaan, halaman yang luas dan memadai sehingga kegiatan yang berlangsung bisa berjalan dengan maksimal. 
Widi Astuti, Cahya Edi Setyawan, Irvan Maulana Aji : Penerapan Biah Lughawiyah Dalam Pembiasaan Maharah Kalam Di Pondok Pesantren Ibnul Qayyim Putra Yogyakarta

Selanjutnya faktor penghambatnya adalah keadaan semangat santri yang turun. Karena dengan turunya semangat santri akan menghambat proses kegiatan bi'ah lughowiyyah. Untuk itu dorongan semangat dan motivasi sangat berperan besar. 
Widi Astuti, Cahya Edi Setyawan, Irvan Maulana Aji : Penerapan Biah Lughawiyah

Dalam Pembiasaan Maharah Kalam Di Pondok Pesantren Ibnul Qayyim Putra

Yogyakarta

\section{Daftar Pustaka}

'Alim A Ibrahim, Al-Muwajjih al-Fanni' li Mudarrisi al-Lugah al‘Arabiyyah (Al-Qahirah: Dar al-Ma'arif, 1978)

Ashari A, Skripsi : "Peranan Pembimbing Asrama Dalam Meningkatkan Keterampilan Berbahasa Arab Dan Inggris Siswa Madrasah Mu'alimin Muhammadiyah Yogyakarta ",(Yogyakarta: Universitas Muhammadiyah Yogyakarta, 2012)

Eka Y Rustika, Skripsi : “Upaya Penciptaan Bi'ah Lughowiyyah Melalui Optimalisasi Pembelajaran Al-Kalam di Jurusan Pendidikan Bahasa Arab Fakultas Ilmu Tarbiyyah dan Keguruan UIN Sunan Kalijaga Yogyakarta". (Yogyakarta, Universitas Islam Negri Sunan Kalijaga, 2014)

Bisri Mustofa dan Abdul Hamid, Metode Dan Strategi Pembelajaran Bahasa Arab, (Malang: UIN MALIKI PRESS, 2012)

Hasbi Ash-Shiddieqy, Falsafah Hukum Islam (Jakarta:Bulan Bintang, 1975),

Fuad Efendy A, Metodologi Pengajaran Bahasa Arab, (Malang: Misykat, 2005)

Halimah L, Keterampilan Mengajar, (Bandung: Refika Aditama, 2017)

Hermawan A, Metodologi Pembelajaran Bahasa Arab, (Bandung: Remaja Rosdakarya, 2011)

Syaiful Mustofa, Strategi Pembelajaran Bahasa Arab Inovatif, (Malang: UIN MALIKI PRESS,2011)

R. Ibrahim dan Nana Syaodih, Perencanaan Pembelajaran, (Jakarta: Rineka Cipta, 2010), 
Widi Astuti, Cahya Edi Setyawan, Irvan Maulana Aji : Penerapan Biah Lughawiyah Dalam Pembiasaan Maharah Kalam Di Pondok Pesantren Ibnul Qayyim Putra Yogyakarta

Putri N, Al-Ta'lim: "Bi'ah 'Arabiyyah", (IAIN Imam Bonjol Padang, 2013, Volume 1, Nomor 5).

Wahid A Wafi, Al Lughah wa Al Mujtama', (Kairo: Dar al-Nahdhat Mishr, 1971) 